\title{
Article \\ The Nutritional Composition of Natural and Organic Branded Food Products: A Cross-Sectional Analysis of the Greek Foodscape
}

\author{
Alexandra Katidi, Anthi Pavlopoulou (D, Antonis Vlassopoulos (D) and Maria Kapsokefalou * \\ Department of Food Science \& Human Nutrition, Agricultural University of Athens, 11855 Athens, Greece; \\ alexandra_katidi@aua.com (A.K.); anthipvl_3@yahoo.gr (A.P.); avlassopoulos@aua.gr (A.V.) \\ * Correspondence: kapsok@aua.gr; Tel.: +30-210-5294708
}

check for updates

Citation: Katidi, A.; Pavlopoulou, A.; Vlassopoulos, A.; Kapsokefalou, M. The Nutritional Composition of Natural and Organic Branded Food Products: A Cross-Sectional Analysis of the Greek Foodscape. Nutrients 2022, 14, 808. https://doi.org/ $10.3390 /$ nu14040808

Received: 12 January 2022

Accepted: 11 February 2022

Published: 14 February 2022

Publisher's Note: MDPI stays neutral with regard to jurisdictional claims in published maps and institutional affiliations.

Copyright: (C) 2022 by the authors. Licensee MDPI, Basel, Switzerland. This article is an open access article distributed under the terms and conditions of the Creative Commons Attribution (CC BY) license (https:// creativecommons.org/licenses/by/ $4.0 /)$.

\begin{abstract}
Modern consumers turn to foods marketed as 'natural/organic' in their pursuit of healthier options. However, research that links such claims made on pack with improved nutritional composition is limited. The current analysis used data from all packaged foods available in the Hellenic Food Thesaurus ( $n=4002$ ), sold in Greece from $09 / 2020$ to $01 / 2021$, to map the prevalence of packaged foods sold under a 'natural/organic' claim and to compare their nutritional composition against food group matched conventional counterparts. Statistical analysis was carried out using IBM SPSS Statistics ${ }^{\circledR}$. Overall, 'free from' was the most commonly used claim $(12.3 \%)$, followed by 'natu$\mathrm{ral} /$ pure' (9.1\%), 'fresh' (4.6\%), and 'bio/organic' (3.3\%). Statistically significant differences between the nutritional composition of natural/organic and conventional foods were only found in 5 out of the 13 food categories and in 9 out of 39 subcategories. Being labelled as natural/organic was linked to improved nutritional composition for prepared foods and yogurts, while for breakfast cereal, there was a mixed effect with lower carbohydrate content but higher energy and fat content. Jams labelled as natural/organic had higher energy and total sugar content. Overall, evidence of an association between being labelled as natural/organic and having an improved nutritional composition was extremely rare.
\end{abstract}

Keywords: natural; bio/organic; branded foods; packaged foods; claims; nutritional composition

\section{Introduction}

Front-of-pack (FoP) visual and verbal claims play a critical role in capturing consumers' attention, allowing them to quickly judge which product fits their diet and lifestyle needs $[1,2]$. Traditionally, claims made on pack aimed to link a food's composition to specific health effects. However, lately the use of generic claims such as 'healthy' and 'natural' is increasingly seen on packaged foods, potentially as part of a general marketing strategy called the 'health halo' effect $[3,4]$. The intensity of usage of such terms and their ability to create confusion to the consumer has led official bodies such as the Food \& Drug Administration (FDA) to issue definitions on the usage of the term 'healthy' [5-7]. Although the regulations of Nutrition and Health claims made on packaged products have been the topic of legislative and scientific discussion for nearly three decades [8,9], the proliferation of marketing strategies and venues, regulating an ever-expanding food labelling environment, requires constant vigilance [10] in order to ensure that any claim made on pack is not misleading and is substantiated by generally accepted scientific data [11].

In addition to functional foods (foods with specific health and nutrition claims), the past 5 years have seen an increase in consumer demand for natural and organic foods. According to legislation, a product is considered natural when 'it contains no artificial ingredient or added color and is only minimally processed. Minimal processing means that the product was processed in a manner that does not fundamentally alter the product. The label must include a statement explaining the meaning of the term natural (such as "no 
artificial ingredients; minimally processed" ${ }^{\prime}$ '. Similarly, organic food is any food produced without the use of artificial fertilizers (grown on soil that is restored only with organic fertilizers); without pesticides, growth regulators, antibiotics, hormones, and many other types of chemicals; and processed without the use of additives and chemical preservatives that are popular in the modern food industry [12,13].

Consumers are increasingly more aware and more willing to pay a price premium for organic or natural foods [14-16]. However, the increase in consumer demand for natural and organic products is only partially attributed to an increase in consumer awareness of such products [15-17]. Consumers are more likely to purchase organic products when they offer multiple benefits that cover a range of beliefs and attitudes. For example, previous research has linked the willingness to purchase organic foods with statements regarding improved animal welfare, a link to a product's local origin, and its environmental impact, as well as the product's nutritional value [14,18-21]. As far as nutritional value is concerned, consumers often assign higher nutritional value to both organic and natural foods, and this improved nutritional value is linked to a perceived improvement in the nutritional composition of foods labeled as organic or natural $[9,19,22]$. The importance of nutritional value as an element of organic/natural foods for the consumer is so great that in the absence of such a nutritional superiority, the added value assigned to the product diminishes greatly [23].

Despite consumer perceptions, research to date does not support the hypothesis that natural and/or organic foods have indeed an improved nutritional composition, except from small differences in selected nutrients [23]. Those differences are most commonly found in micronutrients and phytochemicals rather than macronutrients [24]. As micronutrient and phytochemical content are not part of the nutritional declaration made on pack, it is important to understand whether any consumer perception around the nutritional superiority of organic/natural foods could be readily justified on the basis of the information available to the consumer on pack. Unfortunately, research in this area is limited, as it requires access to large datasets with data on organic/natural foods and matched conventional counterparts to allow for head-to-head comparisons.

The Hellenic Food Thesaurus (HelTH) was established in 2019 as a tool to map and track packaged food product sold in Greece. HelTH tracks nutritional composition and all statements made on pack for $\approx 4000$ products and it allows for cross-sectional analysis on the link between marketing statements and the nutritional composition of foods. For the current analysis, HelTH was used to quantify the prevalence and type of natural and organic/GMO-free claims on packaged foods sold in Greece, and we compared the nutritional composition of those products against category-matched conventional counterparts. The main research hypothesis was that a product's natural or organic nature has limited impact on its final nutritional composition in macronutrients.

\section{Materials and Methods}

\subsection{The HelTH Database}

The Hellenic Food Thesaurus (HelTH), the Branded Food Composition Database of the Agricultural University of Athens, was used for data extraction (HelTH is a dynamic dataset that collects information on packaged foods sold in Greece, and it was first implemented in 2019. In brief, HelTH includes information on the nutritional composition of foods, any health and/or nutrition claims made on pack, and information on any other quality claims written on pack (environmental claims, logos, origin, etc.). A detailed description of the methodology and structure of HelTH has been published previously [25].

The first version of HelTH $(11 / 2019)$ was used for the current analysis $(n=4002)$. Data were selected on the basis of the availability of nutritional composition data and the availability of data on specific marketing claims. The claims used for the current analysis were extracted from the variables including on-pack communication related to the naturality of products, their organic production, their relationship with the environment, and other social aspects. 
All information around claims and the nutritional composition was taken from the packaging and entered into the database. Claims from all sides of the packaging were identified. Claims included both graphical indicators (logos) and text. All visible text was considered a claim, including brand slogans. Due to the fact that 'natural' claims-except biological/organic - have not been authorized or defined, data entered at these variables are varied, and further organization was needed. For the purpose of this study, a review of the claims entered at the database was conducted, and thus all variations in wording of naturality were identified (Table 1).

Table 1. Variations in wording used for natural and other claims.

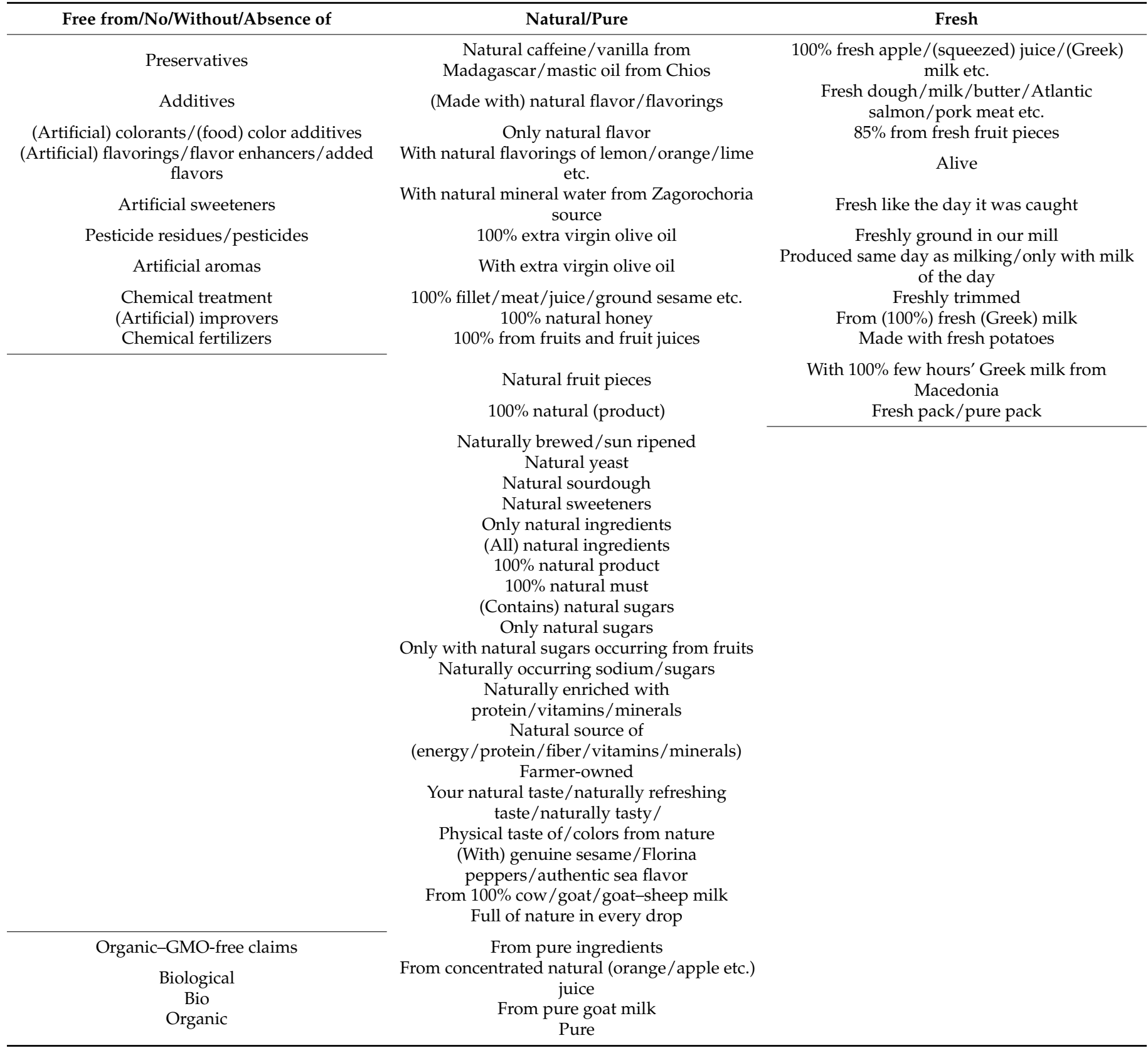

\subsection{Data Selection and Cleaning}

All data of the HelTH Branded Food Composition Database (BFCD) were checked and cleaned. In particular, duplicates of the same product, constituting part of an offer or 
discount multi-package, or by human error appearing twice at the online platform, were excluded (multi-pack items were deleted where the single item was also available).

For the purpose of the study, products that did not contain any data about the claims (health, nutrition, organic, natural, etc.) $(n=96)$ were considered ineligible and were excluded. Furthermore, in analyses that included nutritional data, products missing nutrient information (e.g., energy, saturated fatty acids (SFA), sugar, sodium, protein, and fiber) due to the data collection and data entry methodology limitations (no access to photographs of all the sides of the products' packaging or photographs not clear enough to copy data or researchers' error) were also excluded $(n=341)$ (Figure 1$)$.

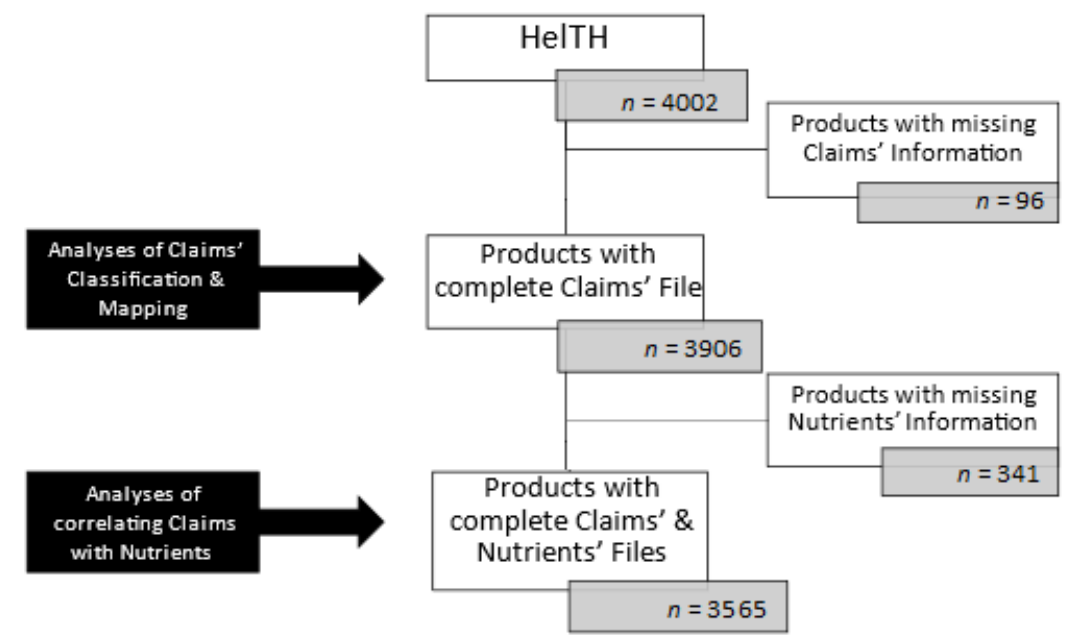

Figure 1. Flow chart of the products included in the analyses of this study. HelTH, Hellenic Food Thesaurus.

\subsection{Analysis}

Statistical analysis was carried out using IBM SPSS Statistics ${ }^{\circledR}$ (version 23, Northridge, CA, USA). Nutritional composition data were analyzed as continuous variables (content per $100 \mathrm{~g}$ or $100 \mathrm{~mL}$ of product). Data were tested for normality using the Kolmogorov-Smirnov test. None of the variables followed the normal distribution. Therefore, variables were expressed as median (interquartile range). Differences were tested using the Kruskal-Wallis non-parametric test for $\mathrm{k}$ independent samples. Between-group differences were tested using the Mann-Whitney U test for continuous variables. Statistical significance was set at $0.01 \%$ to adjust for multiple comparisons (Bonferroni correction).

\section{Results}

\subsection{Categorization and Number of Claims}

After processing the differences in wording and clustering their meanings, we classified claims for naturality and biological production into five groups. Table 2 provides an overview of the expressions of natural and other organic/genetically modified organisms (GMO)-free claims displayed on Greek foods. Claims for naturality were grouped into 'free from' claims $(n=471)$, 'natural/pure' $(n=349)$, or 'fresh' $(n=177)$, and other claims were categorized as a product being either biological/organic $(n=127)$ or GMO-free $(n=47)$. Other claim categories referring to the packaging: fresh pack $(n=20)$ and recyclable packaging $(n=428)$, as well as social claims: respect to the environment $(n=59)$, animal welfare $(n=46)$, sustainability $(n=45)$, and employee support $(n=34)$ were considered out of the scope for the present study and were excluded from the current analyses. 
Table 2. Classification and number of natural and environment-related claims existing in the packaging of the branded food products of the HelTH BFCD.

\begin{tabular}{|c|c|c|c|c|c|c|c|}
\hline \multicolumn{3}{|c|}{ Products with Claims } & \multicolumn{5}{|c|}{ Claims Per Product $n(\%)$} \\
\hline & & $n(\%)$ & 1 & 2 & 3 & 4 & 5 \\
\hline & Claims about naturality & $853(22.2)$ & $536(14.0)$ & $220(5.7)$ & $65(1.7)$ & $23(0.6)$ & $1(0.0)$ \\
\hline \multirow[t]{8}{*}{ Free from } & & 471 (12.3) & $299(7.8)$ & $\begin{array}{c}123 \\
(3.2)\end{array}$ & 49 (1.3) & & \\
\hline & No preservatives & $415(10.8)$ & & & & & \\
\hline & No artificial colorants & $164(4.3)$ & & & & & \\
\hline & $\begin{array}{l}\text { No artificial flavorings / } \\
\text { flavor enhancers }\end{array}$ & $83(2.2)$ & & & & & \\
\hline & No additives & $16(0.4)$ & & & & & \\
\hline & No pesticides & $6(0.2)$ & & & & & \\
\hline & No chemical fertilizers/processing & $5(0.1)$ & & & & & \\
\hline & No improvers & $3(0.1)$ & & & & & \\
\hline \multirow[t]{5}{*}{ Natural/Pure } & & $349(9.1)$ & $301(7.8)$ & $46(1.2)$ & $2(0.1)$ & & \\
\hline & Natural ingredients & $190(4.9)$ & & & & & \\
\hline & Natural product & $88(2.3)$ & & & & & \\
\hline & Natural taste/flavor/color & $81(2.1)$ & & & & & \\
\hline & Natural source of nutrients & $29(0.8)$ & & & & & \\
\hline \multirow[t]{3}{*}{ Fresh } & & $157(4.6)$ & $157(100)$ & & - & & \\
\hline & Fresh ingredients & $93(2.4)$ & & & & & \\
\hline & Fresh product & $64(1.7)$ & & & & & \\
\hline & Other claims & $172(4.3)$ & $169(4.2)$ & $3(0.1)$ & & & \\
\hline Bio-Organic & & $127(3.3)$ & & & & & \\
\hline GMO-free & & 47 (1.2) & & & & & \\
\hline
\end{tabular}

Overall, $22 \%(n=853)$ of the products carried at least one claim for being natural, while less than $5 \%$ of the products $(n=172)$ carried other organic-GMO-free claims. The most prevalent claim was the absence of preservatives, found at about half $(48.7 \%)$ of the products carrying a 'natural' claim, was followed by the 'natural ingredients' claim found at $22.3 \%$ of these products. The average number of 'natural' claims per product was 1.5 , while nearly none $(0.1 \%)$ of the products combined a bio/organic and 'GMO-free' claim. A total of $10.6 \%(n=90)$ of the products bearing a 'natural' claim had a relevant logo on their packaging, while the majority of the products with an organic-GMO-free claim were accompanied by the relevant logo (aligned with legislator obligations) [26].

The prevalence of natural and organic-GMO-free claims was assessed overall and by food categories and subcategories. In total, 1171 food products $(30.0 \%)$ carried claims on 'naturality', organic production, and/or absence of GMOs. The detailed distribution of those claims per food category and subcategory is presented at Table 4. More than a quarter of the 'free from' claims (28.9\%) and 'natural/pure' claims $(28.7 \%)$ were found in 'the grain or grain product' category, and most of them $(44.1 \%$ and $44.0 \%$, respectively) were in the 'bread or similar product' subcategory. 'Fresh' claims were more prevalent in the 'milk, milk product, or substitute' category. Bio/organic claims were found in 10 out of 13 food categories, with percentages varying from $0.6 \%$ to $8.2 \%$, except for the 'egg or egg product' category, wherein more than one-third of the products $(37.1 \%)$ were characterized as biological. The 'GMO-free' claim appeared on the packaging of 47 food products in total, belonging to specific food categories, the majority of them $(59.6 \%)$ to the 'milk, milk product, or substitute' category. 
Table 3. Prevalence of natural and organic-GMO-free claims through the food categories and subcategories of the HelTH BFCD.

\begin{tabular}{|c|c|c|c|c|c|}
\hline & Free From & Natural/Pure & Fresh & Bio-Organic & GMO-Free \\
\hline Food Categories and Subcategories & $n(\%)$ & $n(\%)$ & $n(\%)$ & $n(\%)$ & $n(\%)$ \\
\hline Milk, milk product, or milk substitute $(n=693)$ & $69(10.0)$ & $62(8.9)$ & $64(9.2)$ & $29(4.2)$ & $28(4.0)$ \\
\hline Milk $(n=175)$ & $8(4.6)$ & $22(12.6)$ & $0(0.0)$ & $12(6.9)$ & $10(5.7)$ \\
\hline Yogurt $(n=172)$ & $30(17.4)$ & $16(9.3)$ & $46(26.7)$ & $5(2.9)$ & $8(4.7)$ \\
\hline Cheese $(n=212)$ & $10(4.7)$ & $18(8.5)$ & $17(8.0)$ & $6(2.8)$ & $0(0.0)$ \\
\hline Cream $(n=42)$ & $12(28.6)$ & $0(0.0)$ & $11(26.2)$ & $0(0.0)$ & $0(0.0)$ \\
\hline Imitation milk products $(n=52)$ & $8(15.4)$ & $4(7.7)$ & $0(0.0)$ & $6(11.5)$ & $10(19.2)$ \\
\hline Frozen dairy desserts $(n=40)$ & $1(2.5)$ & $2(5.0)$ & $0(0.0)$ & $0(0.0)$ & $0(0.0)$ \\
\hline Egg or egg product $(n=35)$ & $4(11.4)$ & $0(0.0)$ & $0(0.0)$ & $13(37.1)$ & $7(20.0)$ \\
\hline Fresh or processed egg $(n=35)$ & $4(11.4)$ & $0(0.0)$ & $0(0.0)$ & $13(37.1)$ & $7(20.0)$ \\
\hline Meat or meat product $(n=156)$ & $1(0.6)$ & $4(2.6)$ & $13(8.3)$ & $1(0.6)$ & $0(0.0)$ \\
\hline Preserved meat products $(n=89)$ & $0(0.0)$ & $1(1.1)$ & $6(6.7)$ & $0(0.0)$ & $0(0.0)$ \\
\hline Sausage or similar meat products $(n=38)$ & $1(2.6)$ & $3(7.9)$ & $7(18.4)$ & $1(2.6)$ & $0(0.0)$ \\
\hline Meat dish $(n=26)$ & $0(0.0)$ & $0(0.0)$ & $0(0.0)$ & $0(0.0)$ & $0(0.0)$ \\
\hline Seafood or related product $(n=80)$ & $6(7.5)$ & $8(10.0)$ & $1(1.3)$ & $0(0.0)$ & $0(0.0)$ \\
\hline Seafood products $(n=80)$ & $6(7.5)$ & $8(10.0)$ & $1(1.3)$ & $0(0.0)$ & $0(0.0)$ \\
\hline Fat or oil $(n=81)$ & $7(8.6)$ & $10(12.3)$ & $0(0.0)$ & $4(4.9)$ & $0(0.0)$ \\
\hline Vegetable fat or oil $(n=8)$ & $0(0.0)$ & $1(12.5)$ & $0(0.0)$ & $0(0.0)$ & $0(0.0)$ \\
\hline Margarine or fat from mixed origin $(n=39)$ & $5(12.8)$ & $1(2.6)$ & $0(0.0)$ & $1(2.6)$ & $0(0.0)$ \\
\hline Butter or other animal fat $(n=34)$ & $2(5.9)$ & $8(23.5)$ & $0(0.0)$ & $3(8.8)$ & $0(0.0)$ \\
\hline Grain or grain product $(n=1129)$ & $136(12.7)$ & $100(9.3)$ & $34(2.2)$ & $29(2.7)$ & $1(0.1)$ \\
\hline Cereal or similar milling product $(n=51)$ & $0(0.0)$ & $0(0.0)$ & $9(17.6)$ & $0(0.0)$ & $0(0.0)$ \\
\hline Rice or similar grain $(n=89)$ & $2(2.2)$ & $0(0.0)$ & $0(0.0)$ & $7(7.9)$ & $0(0.0)$ \\
\hline Pasta or similar product $(n=203)$ & $0(0.0)$ & $0(0.0)$ & $0(0.0)$ & $11(5.4)$ & $0(0.0)$ \\
\hline Breakfast cereal $(n=150)$ & $30(30.3)$ & $23(23.2)$ & $0(0.0)$ & $2(2.0)$ & $0(0.0)$ \\
\hline Bread or similar product $(n=259)$ & $60(23.2)$ & $44(17.0)$ & $23(8.9)$ & $8(3.1)$ & $1(0.4)$ \\
\hline Fine bakery ware $(n=289)$ & $19(6.6)$ & $13(4.5)$ & $2(0.7)$ & $1(0.3)$ & $0(0.0)$ \\
\hline Savory cereal dish $(n=83)$ & $25(30.1)$ & $20(24.1)$ & $0(0.0)$ & $0(0.0)$ & $0(0.0)$ \\
\hline Nut, seed, or kernel $(n=131)$ & $15(11.5)$ & $30(22.9)$ & $0(0.0)$ & $7(5.3)$ & $0(0.0)$ \\
\hline Nuts $(n=69)$ & $0(0.0)$ & $0(0.0)$ & $0(0.0)$ & $1(1.4)$ & $0(0.0)$ \\
\hline Seeds or kernels $(n=35)$ & $6(17.1)$ & $13(37.1)$ & $0(0.0)$ & $4(11.4)$ & $0(0.0)$ \\
\hline Nut/seed product $(n=27)$ & $9(33.3)$ & $17(63.0)$ & $0(0.0)$ & $2(7.4)$ & $0(0.0)$ \\
\hline Vegetable or vegetable product $(n=244)$ & $45(18.4)$ & $4(1.6)$ & $8(3.3)$ & $20(8.2)$ & $0(0.0)$ \\
\hline Vegetable (excluding potato) $(n=172)$ & $40(23.3)$ & $4(2.3)$ & $0(0.0)$ & $16(9.3)$ & $0(0.0)$ \\
\hline Starchy root or potato $(n=21)$ & $5(23.8)$ & $0(0.0)$ & $8(38.1)$ & $0(0.0)$ & $0(0.0)$ \\
\hline Pulse or pulse products $(n=51)$ & $0(0.0)$ & $0(0.0)$ & $0(0.0)$ & $4(7.8)$ & $0(0.0)$ \\
\hline Fruit or fruit product $(n=45)$ & $2(4.4)$ & $0(0.0)$ & $0(0.0)$ & $0(0.0)$ & $0(0.0)$ \\
\hline Processed fruit product $(n=45)$ & $2(4.4)$ & $0(0.0)$ & $0(0.0)$ & $0(0.0)$ & $0(0.0)$ \\
\hline Sugar or sugar product $(n=359)$ & $55(15.3)$ & $23(6.4)$ & $12(3.3)$ & $10(2.8)$ & $5(1.4)$ \\
\hline Jam or marmalade $(n=83)$ & $23(27.7)$ & $11(13.3)$ & $9(10.8)$ & $2(2.4)$ & $0(0.0)$ \\
\hline
\end{tabular}


Table 3. Cont.

\begin{tabular}{|c|c|c|c|c|c|}
\hline & Free From & Natural/Pure & Fresh & Bio-Organic & GMO-Free \\
\hline Food Categories and Subcategories & $n(\%)$ & $n(\%)$ & $n(\%)$ & $n(\%)$ & $n(\%)$ \\
\hline $\begin{array}{l}\text { Non-chocolate confectionary or other sugar } \\
\text { product }(n=68)\end{array}$ & $26(38.2)$ & $3(4.4)$ & $0(0.0)$ & $4(5.9)$ & $3(4.4)$ \\
\hline Chocolate $(n=208)$ & $6(2.9)$ & $9(4.3)$ & $3(1.4)$ & $4(1.9)$ & $2(1.0)$ \\
\hline Beverage (non-milk) $(n=412)$ & $62(15.5)$ & $88(21.9)$ & $25(6.2)$ & $5(1.3)$ & $3(0.7)$ \\
\hline Juice or nectar $(n=165)$ & $44(26.7)$ & $35(21.2)$ & $25(15.2)$ & $5(3.0)$ & $3(1.8)$ \\
\hline Non-alcoholic beverage $(n=247)$ & $18(7.6)$ & $53(22.5)$ & $0(0.0)$ & $0(0.0)$ & $0(0.0)$ \\
\hline Miscellaneous food products $(n=457)$ & $61(13.3)$ & $17(3.7)$ & $9(2.0)$ & $9(2.0)$ & $2(0.4)$ \\
\hline Spice, condiment, or other ingredient $(n=283)$ & $36(12.7)$ & $5(1.8)$ & $0(0.0)$ & $4(1.4)$ & $0(0.0)$ \\
\hline Prepared food product $(n=174)$ & $25(14.4)$ & $12(6.9)$ & $9(5.2)$ & $5(2.9)$ & $2(1.1)$ \\
\hline Ready meals $(n=84)$ & $8(9.5)$ & $3(3.6)$ & $1(1.2)$ & $0(0.0)$ & $1(1.2)$ \\
\hline Ready-to-eat meals $(n=43)$ & $0(0.0)$ & $1(2.3)$ & $0(0.0)$ & $0(0.0)$ & $0(0.0)$ \\
\hline Frozen, semi-ready meals $(n=41)$ & $8(19.5)$ & $2(4.9)$ & $1(2.4)$ & $0(0.0)$ & $1(2.4)$ \\
\hline Total $(n=3906)$ & $471(12.3)$ & $349(9.1)$ & $177(4.6)$ & $127(0.3)$ & $47(1.2)$ \\
\hline
\end{tabular}

\subsection{Nutritional Composition of Products Bearing 'Natural' and Organic-GMO-Free Claims}

As the distribution of claims on 'naturality', organic, and GMO-free labels were not evenly distributed across the food groups, it was paramount that any differences in the nutritional composition of natural, organic, and GMO-free foods were tested against conventional counterparts in the same food group. Analysis within the same food subcategory showed that differences between natural and/or organic-GMO-free and conventional foods were only found in 5 out of the 13 food categories and for specific claims (Table 4). The results of those five categories are described in detail below.

In the 'milk, milk product, or milk substitute' category, being labeled as fresh was associated with significantly lower carbohydrates and total sugar content $(p<0.001)$, but only for yogurts and not the remainder of the category.

In the 'grain or grain product' category, statistically significant differences could be found in the 'cereal or cereal-like milling product or derivatives' subcategory for total sugars $(p<0.001)$. In the 'pasta or similar product' subcategory, being labelled as organic was associated with lower protein content $(p<0.001)$. In the 'breakfast cereals' subcategory, differences were only found for products labelled as natural, and they all exhibited higher content of total fat, saturated fatty acids (SFA), carbohydrates, and energy $(p<0.001)$, while in the 'fine bakery wares' subcategory, products labelled as 'free from' had a higher total sugar content $(p<0.001)$.

In the 'sugar or sugar product' category, products in the 'jam or marmalade' subcategory showed statistically significantly higher energy, carbohydrate, and total sugar contents $(p \leq 0.001)$ when labelled as fresh compared to products without such a claim.

In the 'beverage (non-milk)' category, products belonging to the 'juice or nectar' subcategory bearing a natural claim presented themselves as significantly lower in carbohydrates and total sugars and higher in salt content $(p<0.001)$ than conventional products. On the contrary, 'juices or nectars' labelled as fresh had significantly higher protein content and significantly lower energy and salt content $(p \leq 0.001)$ than the conventional products. For this particular food category, it is important highlight that despite statistical significance, the absolute content in protein, total fats, and salt is very low, irrespective of any on pack claims.

Within the 'miscellaneous food products' category, 'spice, condiment, or other ingredient' labelled as 'free from' had significantly lower content of energy, carbohydrates, total sugars, salt, fiber, and protein $(p<0.001)$ than products without such claims. For the 'prepared food products' labelled as 'free from', they were associated with significantly lower in energy, total fat, saturated fat, carbohydrate, and salt content $(p \leq 0.001)$, whereas being labelled as 'fresh' was associated with significantly lower energy and salt content $(p \leq 0.001)$. 
Table 4. Nutritional comparison of products bearing natural or bio/GMO claims and conventional products in the subcategories that presented statistically significant differences.

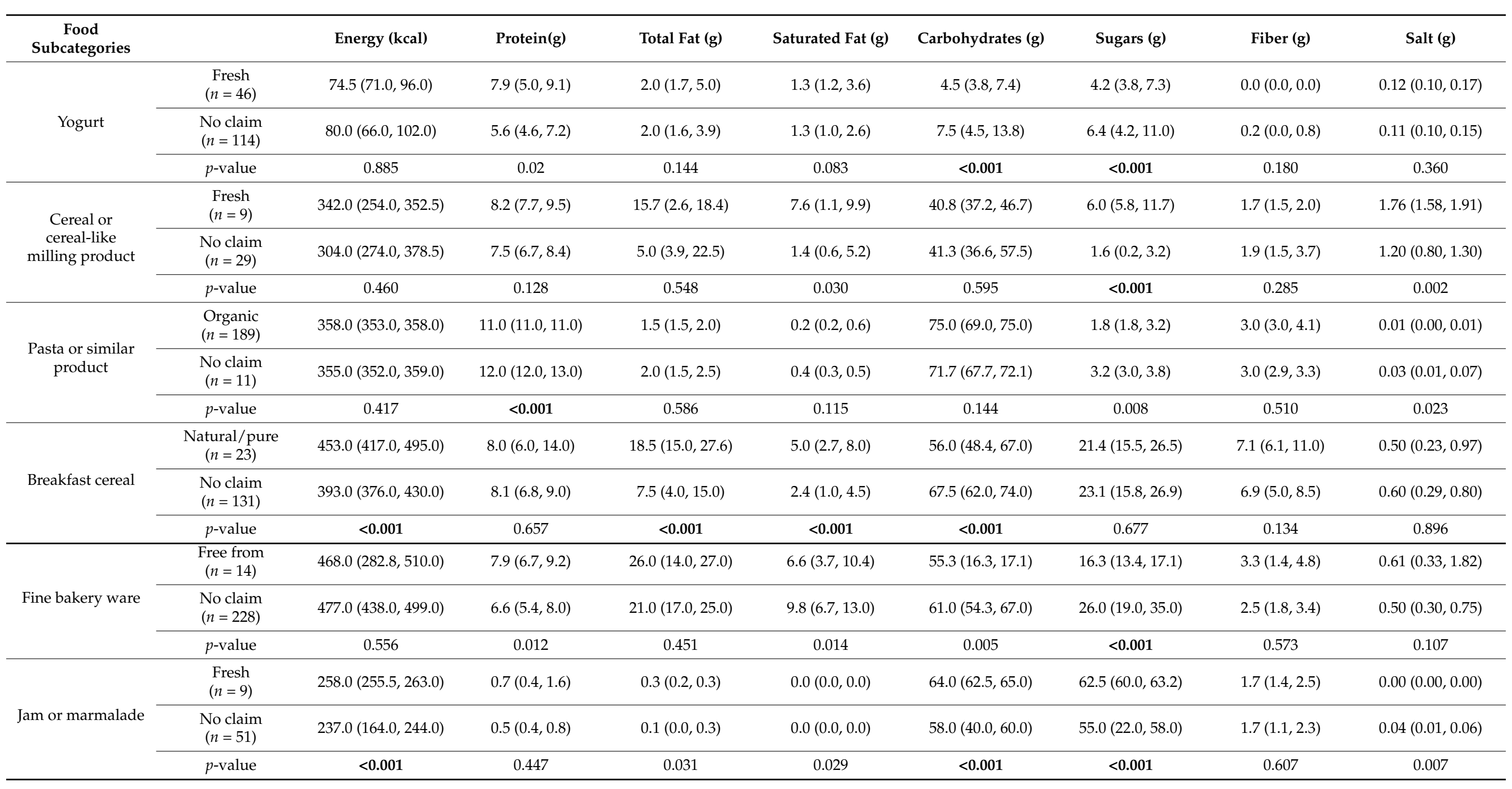


Table 4. Cont.

\begin{tabular}{|c|c|c|c|c|c|c|c|c|c|}
\hline $\begin{array}{c}\text { Food } \\
\text { Subcategories }\end{array}$ & & Energy (kcal) & Protein(g) & Total Fat (g) & Saturated Fat (g) & $\begin{array}{c}\text { Carbohydrates } \\
\text { (g) }\end{array}$ & Sugars (g) & Fiber (g) & Salt (g) \\
\hline \multirow{8}{*}{ Juice or nectar } & $\begin{array}{l}\text { Free from } \\
(n=44)\end{array}$ & $47.9(41.0,51.0)$ & $0.3(0.2,0.5)$ & $0.0(0.0,0.2)$ & $0.0(0.0,0.0)$ & $11.5(10.1,12.2)$ & $10.5(9.1,11.8)$ & $0.4(0.2,0.6)$ & $0.00(0.00,0.02)$ \\
\hline & $\begin{array}{l}\text { No claim } \\
(n=118)\end{array}$ & $49.0(46.0,52.0)$ & $0.4(0.2,0.6)$ & $0.0(0.0,0.1)$ & $0.0(0.0,0.0)$ & $11.8(11.0,12.3)$ & $11.4(10.4,12.0)$ & $0.5(0.4,0.6)$ & $0.00(0.00,0.01)$ \\
\hline & $p$-value & 0.127 & 0.169 & 0.214 & $<0.001$ & 0.109 & 0.024 & 0.200 & 0.224 \\
\hline & $\begin{array}{l}\text { Natural/pure } \\
\quad(n=35)\end{array}$ & $46.0(44.0,48.4)$ & $0.4(0.2,0.4)$ & $0.0(0.0,0.1)$ & $0.0(0.0,0.0)$ & $11.0(10.7,11,7)$ & $10.4(9.5,10.9)$ & $0.5(0.3,0.6)$ & $0.03(0.01,0.03)$ \\
\hline & $p$-value & $<0.001$ & 0.815 & 0.180 & $<0.001$ & $<0.001$ & $<0.001$ & 0.471 & $<0.001$ \\
\hline & $\begin{array}{l}\text { Fresh } \\
(n=25)\end{array}$ & $48.0(46.5,50.5)$ & $0.6(0.5,0.7)$ & $0.0(0.0,0.1)$ & $0.0(0.0,0.0)$ & $11.2(11.0,12.0)$ & $10.5(10.0,11.7)$ & $0.3(0.1,1.2)$ & $0.00(0.00,0.00)$ \\
\hline & $\begin{array}{l}\text { No claim } \\
(n=137)\end{array}$ & $49.0(45.0,52.0)$ & $0.3(0.2,0.5)$ & $0.0(0.0,0.1)$ & $0.0(0.0,0.0)$ & $11.8(10.9,12.4)$ & $11.2(10.4,12.0)$ & $0.5(0.4,0.6)$ & $0.00(0.00,0.02)$ \\
\hline & $p$-value & 0.952 & $<0.001$ & 0.821 & 0.324 & 0.280 & 0.117 & 0.613 & $<0.001$ \\
\hline \multirow{3}{*}{ Spice, condiments } & $\begin{array}{l}\text { Free from } \\
(n=36)\end{array}$ & $6.0(5.0,47.5)$ & $0.5(0.5,0.5)$ & $0.5(0.5,0.5)$ & $0.2(0.2,0.3)$ & $0.5(0.5,1.4)$ & $0.5(0.5,1.2)$ & $0.5(0.5,0.5)$ & $1.04(0.88,1.20)$ \\
\hline & $\begin{array}{l}\text { No claim } \\
(n=211)\end{array}$ & $149(93.0,334.4)$ & $2.8(1.2,5.3)$ & $4.6(0.5,18.9)$ & $0.7(0.1,4.7)$ & $15.0(6.5,24.4)$ & $6.2(3.9,21.6)$ & $1.5(1.0,2.7)$ & $1.80(1.00,3.45)$ \\
\hline & $p$-value & $<0.001$ & $<0.001$ & $<0.001$ & 0.027 & $<0.001$ & $<0.001$ & $<0.001$ & $<0.001$ \\
\hline \multirow{6}{*}{$\begin{array}{l}\text { Prepared food } \\
\text { products }\end{array}$} & $\begin{array}{l}\text { Free from } \\
(n=22)\end{array}$ & $116.0(27.3,293.8)$ & $1.1(0.7,6.3)$ & $1.3(0.5,3.8)$ & $0.3(0.1,1.2)$ & $5.7(4.4,37.8)$ & $2.5(0.8,8.0)$ & $0.5(0.5,1.7)$ & $0.89(0.30,1.03)$ \\
\hline & $\begin{array}{l}\text { No claim } \\
(n=131)\end{array}$ & $365.0(247.0,505.0)$ & $3.8(2.1,7.0)$ & $23.4(6.0,30.4)$ & $4.3(1.7,6.3)$ & $45.8(8.4,57.7)$ & $1.7(0.6,3.7)$ & $2.0(1.0,5.0)$ & $1.50(0.90,1.83)$ \\
\hline & $p$-value & $<0.001$ & 0.015 & $<0.001$ & $<0.001$ & $<0.001$ & 0.176 & 0.004 & $<0.001$ \\
\hline & $\begin{array}{l}\text { Fresh } \\
(n=8)\end{array}$ & $123.0(95.3,130.5)$ & $3.0(2.6,3.1)$ & $4.0(3.1,4.8)$ & $2.6(1.9,5.9)$ & $18.3(14.8,21.7)$ & $8.1(1.7,16.0)$ & $0.1(0.0,0.1)$ & $0.16(0.10,0.23)$ \\
\hline & $\begin{array}{l}\text { No claim } \\
(n=145)\end{array}$ & $357.0(214.0,503.5)$ & $3.7(1.5,7.0)$ & $21.3(3.6,30.4)$ & $3.7(1.0,5.5)$ & $40.1(7.2,57.4)$ & $1.7(0.6,4.0)$ & $1.9(0.8,5.0)$ & $1.40(0.88,1.80)$ \\
\hline & $p$-value & $<0.001$ & 0.283 & 0.035 & 0.960 & 0.431 & 0.089 & 0.002 & $<0.001$ \\
\hline
\end{tabular}

Values represent median (Q1, Q3). All statistical analyses were carried out with the Mann-Whitney U test. Bold highlights statistically significant values ( $p \leq 0.001)$. 


\section{Discussion}

The present study investigated the differences in the nutritional composition of foods with and without 'natural' and organic/GMO claims on packaged foods currently sold in Greece. Overall, approximately one-quarter $(22.2 \%)$ of foods of the HelTH BFCD carried at least one natural claim, and $4.3 \%$ carried at least one organic/GMO claim. It appears that when foods carry claims, they tend to carry more than one, which is often the case for natural claims. Natural foods carry one to five claims on their packaging, while 90 of these products carried a logo also related to their naturalness. The prevalence of claims related to products' naturality variates according to the food category $(0.0-22.9 \%)$ and subcategory $(0.0-63.0 \%)$ and the type of claim. Among the food products analyzed, only 127 were bio/organic, usually appearing with small percentages in most of the food categories, while 'GMO-free' claims were prevalent in only specific subcategories.

Overall, yogurts, spice/condiments, prepared foods, jams, and grains were the main categories in which carrying a claim around naturality or being organic was linked to any differences in the nutritional composition. Differences were more commonly seen for total or saturated fat content, followed by energy, total sugars, and salt. It is important to mention that differences were only seen in specific claim categories, even within the same food subcategory. Whether consumers differentiate between the perceived nutritional value of fresh, natural, and organic foods should be further studied.

These findings are particularly important for the discussion around the nutritional quality of products sold under labels such as natural, free from, organic, and GMO-free. According to our findings, such labels are rarely linked to better nutritional composition, despite common consumer beliefs. In fact, it is important to highlight that those findings would be very different if the statistical analysis was not performed in a food category matched manner.

Food category matching is extremely important if consumer protection from misleading marketing is at the heart of any analysis. As food categories have intrinsically different nutritional composition, analysis of the foodscape as a whole would be erroneous and would lead to misguided choices. Conversely, if the current analysis was performed without a food category matching the results would suggest that food products carrying claims for naturality and/or organic-GMO-free claims seem to have lower contents of energy and nutrients compared to their conventional counterparts (data not shown). These tantalizing findings, however, would be merely an artefact of different distribution among food categories rather than a true difference in head-to-head comparisons between identical foods. Even though, as mentioned earlier, nutrition and health-related claims are in the scope of being examined by the scientific community, there is a limited number of studies dealing with natural and other similar claims. According to a study published in 2003 [27] examining the nutrition and health-related claims used on packaged Australian foods, the 'preservative-free' claim was found on $20.1 \%$ of all products and was used on more than $40 \%$ of canned foods, chips, juices, meat substitutes, pretzels, and rice cakes. 'No artificial colors' was claimed on $17.6 \%$ of products, and 'no artificial flavors' on 14.8\%; GMO-free was claimed on $1.7 \%$, and bio/organic on $1.1 \%$ of all products. These results agree to some extent with ours, as the most prevalent claims were also-and in the same order-'no preservatives', 'no artificial colorants', and 'no artificial flavors'. Organic claims (3.3\%) were most common on egg or eggs products (37\%), and GMO-free claims $(1.2 \%)$ were also usual on milk and milk substitutes (4.0\%) in both studies.

Although these claims from a technological standpoint are expected to have a minor impact on the macronutrient composition of a food product $[19,22,23]$, consumers are generally willing to pay high price premiums for products with these attributes as they are perceived to have higher nutritional value [9]. Although some evidence exists to link consumption of organic foods to reduced risk of allergic disease and of overweight and obesity [28-30], this might not be explained via a difference in the macronutrient composition of those products. Our results agree with the Food Labelling of Italian Products (FLIP) Study [23], which indicated that, with few exceptions, organic labelled prepacked 
products were not characterized by a better nutritional composition than conventional ones. Bio/organic claims should not be interpreted by consumers as proxy of 'healthier' food than regular food when comparisons are made between identical food products. A previous systematic review in various food categories also highlighted differences in the micronutrient and phytochemical content of organic foods and not in macronutrients [30].

This is the first comprehensive study, to our knowledge, that deals with natural and organic-GMO-free claims, as well as assessing their prevalence in the Greek marketplace. Aside from providing the first overview and a baseline for the labelling indications in Greece, the present study offers a novel method of classifying natural and organic-GMOfree claims in which the different wording of the same claims was rigorously examined. It is hoped that the categorization developed will provide guidance for other researchers on replicating and advancing future claim prevalence studies, as this approach required more coordination efforts, but we believe that this was appropriate and would be the most suitable method for future similar research. Furthermore, this study assessed the nutritional composition of the products carrying natural and/or organic-GMO-free claims and indicates the necessity of stepping towards making research a useful source of information for future regulation, as it underlines the need of the development of a framework for the unregulated claims existing on food packaging and the need of a system to evaluate the suitability of foods for carrying them and to ensure consumers' protection.

This study had also some limitations worth highlighting. The first is in regard to the lack of market share data and the shortcoming of evaluating the extent to which the HelTH BFCD covers the Greek pre-packaged food market. Secondly, the present study focused on the evaluation of nutritional composition only on the basis of mandatory information, which does not include other nutritional components, such as vitamins, minerals, and bioactive compounds. Moreover, it is important to note that, considering the Regulation 1169/2011 [31], nutrition declaration can be formulated either from direct analysis of food or from data extrapolated from reference databases of food composition, which do not take into account potential differences between natural, organic, and non-organic ingredients.

\section{Conclusions}

Foods labelled as natural and organic/GMO-free are rarely different to their food category-matched conventional counterparts in terms of nutritional composition. In our study, only 9 out of 39 food subcategories showed any evidence of such a difference in nutritional composition. The development of detailed food composition databases that combine labelled data such as organic, natural, and other claims with macro-nutrient, micro-nutrient, and phytochemical composition will be required to further explore potential differences in nutritional quality.

Author Contributions: Conceptualization, A.K. and M.K.; methodology, A.K. and A.V.; formal analysis, A.K. and A.P.; investigation, A.P.; resources, M.K.; data curation, A.K. and A.P.; writing-original draft preparation, A.K.; writing-review and editing, A.V. and M.K.; visualization, A.K.; supervision, M.K.; project administration, A.K., A.V. and M.K. All authors have read and agreed to the published version of the manuscript.

Funding: This research received no external funding.

Institutional Review Board Statement: Not Applicable.

Informed Consent Statement: Not Applicable.

Data Availability Statement: Not Applicable.

Conflicts of Interest: The authors declare no conflict of interest. 


\section{References}

1. Abrams, K.M.; Evans, C.; Duff, B.R.L. Ignorance Is Bliss. How Parents of Preschool Children Make Sense of Front-of-Package Visuals and Claims on Food. Appetite 2015, 87, 20-29. [CrossRef] [PubMed]

2. Purnhagen, K.; van Herpen, E.; van Kleef, E. The Potential Use of Visual Packaging Elements as Nudges. In Nudging-Possibilities, Limitations and Applications in European Law and Economics; Springer International Publishing Inc.: New York, NY, USA, 2016; pp. 197-216.

3. Chandon, P.; Wansink, B. Does Food Marketing Need to Make Us Fat? A Review and Solutions. Nutrition Rev. 2012, 70, 571-593. [CrossRef]

4. Acton, R.B.; Hammond, D. Do Manufacturer "nutrient Claims" Influence the Efficacy of Mandated Front-of-Package Labels? Public Health Nutr. 2018, 21, 3354-3359. [CrossRef] [PubMed]

5. Guidance Documents \& Regulatory Information by Topic (Food and Dietary Supplements). Available online: https: / / www.fda.gov/food/guidance-regulation-food-and-dietary-supplements/guidance-documents-regulatory-informationtopic-food-and-dietary-supplements (accessed on 11 January 2022).

6. FDA Guidelines Registrar. Available online: https://www.registrarcorp.com/fda-guidelines/?lead_source=Google\%20Ad\& utm_source=google\&utm_medium $=$ cpc\&utm_term $=$ fda\%20regulations\&utm_content=114954786914\&utm_campaign=1145 3632246\&matchtype $=p \&$ device $=$ c\&gclid $=$ Cj0KCQjw5PGFBhC2ARIsAIFIMNegRxpDS99F2DRFCFOHnEBOlw1eRd9EgV6 LHCtE_EPfp64GDEXLwksaAmOBEALw_wcB (accessed on 6 June 2021).

7. FDA Food Registration and, US. Available online: https://www.fdahelp.us/fda-food-registration.html?gclid=Cj0KCQjw5PGFBhC2 ARIsAIFIMNdRT0cZ2Hz50cOGxI8LVre3id6AEuA1kIvha-3Q1Ayo7eYSUdhDAicaAlx0EALw_wcB (accessed on 6 June 2021).

8. Codex General Standard for the Labelling of Prepackaged Foods. Available online: https://www.fao.org/3/y2770e/y2770e02. htm\#fn1 (accessed on 11 January 2022).

9. EUR-Lex-32006R1924-EN-EUR-Lex. Available online: https://eur-lex.europa.eu/legal-content/en/ALL/?uri=CELEX\%3A320 06R1924 (accessed on 6 June 2021).

10. Rayner, M.; Wood, A.; Lawrence, M.; Mhurchu, C.N.; Albert, J.; Barquera, S.; Friel, S.; Hawkes, C.; Kelly, B.; Kumanyika, S.; et al. Monitoring the Health-Related Labelling of Foods and Non-Alcoholic Beverages in Retail Settings. Obesity Rev. 2013, 14, 70-81. [CrossRef] [PubMed]

11. Pravst, I. Functional Foods in Europe: A Focus on Health Claims. In Scientific, Health and Social Aspects of the Food Industry; Valdez, B., Ed.; InTechOpen: London, UK, 2012.

12. Natural and Organic Label Claims. Available online: https://www.canr.msu.edu/resources/natural-and-organic-label-claims (accessed on 11 January 2022).

13. Organic Production and Products. Available online: https://ec.europa.eu/info/food-farming-fisheries/farming/organicfarming/organic-production-and-products_en (accessed on 11 January 2022).

14. Cachero-Martínez, S. Risk and Financial Management Consumer Behaviour towards Organic Products: The Moderating Role of Environmental Concern. J. Risk Financ. Manag. 2020, 13, 330. [CrossRef]

15. Asioli, D.; Aschemann-Witzel, J.; Caputo, V.; Vecchio, R.; Annunziata, A.; Næs, T.; Varela, P. Making Sense of the "Clean Label" Trends: A Review of Consumer Food Choice Behavior and Discussion of Industry Implications. Food Res. Int. 2017, 99, 58-71. [CrossRef] [PubMed]

16. Lusk, J.L. Consumer Preferences for Cage-Free Eggs and Impacts of Retailer Pledges. Agribusiness 2019, 35, 129-148. [CrossRef]

17. Consumer Perceptions of 'Natural' Foods. Available online: https://www.ift.org/news-and-publications/food-technologymagazine/issues/2019/july / features / consumer-perceptions-of-natural-foods (accessed on 1 June 2021).

18. Liang, R.-D. Predicting Intentions to Purchase Organic Food: The Moderating Effects of Organic Food Prices. Br. Food J. 2016, 118, 183-199. [CrossRef]

19. Smiglak-Krajewska, M.; Wojciechowska-Solis, J. Consumer versus Organic Products in the COVID-19 Pandemic: Opportunities and Barriers to Market Development. Energies. 2021, 14, 5566. [CrossRef]

20. Gerini, F.; Alfnes, F.; Schjøll, A. Organic-and Animal Welfare-Labelled Eggs: Competing for the Same Consumers? J. Agric. Econ. 2016, 67, 471-490. [CrossRef]

21. Schjøll, A. Country-of-Origin Preferences for Organic Food. Org. Agric. 2016, 7, 315-327. [CrossRef]

22. Luskid, J.L. Consumer Beliefs about Healthy Foods and Diets. PLoS ONE 2019, 14, e0223098. [CrossRef]

23. Dall'Asta, M.; Angelino, D.; Pellegrini, N.; Martini, D. The Nutritional Quality of Organic and Conventional Food Products Sold in Italy: Results from the Food Labelling of Italian Products (Flip) Study. Nutrients. 2020, 12, 1273. [CrossRef] [PubMed]

24. Organic Foods Contribution to Nutritional Quality and Value. Available online: https://reader.elsevier.com/reader/sd/pii/S092 4224417303679?token=D752383C9EA0E82EEC4674CE4C0433AD88509D88822B4182B627EC860F3145A88F56CC8285CFA269 DD197C475E8041DE\&originRegion=eu-west-1\&originCreation=20220208102605 (accessed on 11 January 2022).

25. Katidi, A.; Vlassopoulos, A.; Kapsokefalou, M. Development of the Hellenic Food Thesaurus (HelTH), a Branded Food Composition Database: Aims, Design and Preliminary Findings. Food Chem. 2021, 347, 129010. [CrossRef] [PubMed]

26. The Organic Logo. Available online: https://ec.europa.eu/info/food-farming-fisheries/farming/organic-farming/organiclogo_en (accessed on 11 January 2022).

27. Williams, P.G.; Yeatman, H.; Zakrzewski, S.; Aboozaid, B.; Henshaw, S. Nutrition and Related Claims Used on Packaged Australian Foods-Nutrition and Related Claims Used on Packaged Australian Foods-Implications for Regulation; Research Online-University of Wollongong: Wollongong, Australia, 2003. 
28. Mie, A.; Andersen, H.R.; Gunnarsson, S.; Kahl, J.; Kesse-Guyot, E.; Rembiałkowska, E.; Quaglio, G.; Grandjean, P. Human Health Implications of Organic Food and Organic Agriculture: A Comprehensive Review. Environ. Health. 2017, 16, 111. [CrossRef]

29. Alink, G. Safety and Nutritional Assessment of GM Plants and Derived Food and Feed: The Role of Animal Feeding Trials. Food Chem. Toxicol. 2008, 46, 2-70. [CrossRef]

30. Popa, M.E.; Mitelut, A.C.; Popa, E.E.; Stan, A.; Popa, V.I. Organic Foods Contribution to Nutritional Quality and Value. Trends Food Sci. Technol. 2019, 84, 15-18. [CrossRef]

31. EUR-Lex-32011R1169-EN-EUR. Available online: https://eur-lex.europa.eu/legal-content/EN/ALL/?uri=CELEX\%3A32011 R1169 (accessed on 7 June 2021). 